\title{
Nutritional and functional characteristics of gingerbread plum (Neocarya macrophylla): an underutilized oilseed
}

\author{
By T. Amza, I. Amadou, M.T. Kamara, K. X. Zhu and H. M. Zhou*
}

\author{
State Key Laboratory of Food Science and Technology, School of Food Science and Technology, \\ Jiangnan University \\ No. 1800 Lihu Road, Wuxi, 214122 Jiangsu, People's Republic of China. \\ ( ${ }^{*}$ Corresponding author: amzat_2000@yahoo.fr/hmzhou@jiangnan.edu.cm)
}

\begin{abstract}
RESUMEN
Características funcionales y nutricionales de ciruela de pan de jengibre (Neocarya macrophylla): una semilla infrautilizada.

La digestibilidad de proteínas in vitro, la calidad nutricional de proteínas y las características funcionales (solubilidad de proteínas, capacidad de enlace agua/aceite, capacidad emulsionante y capacidad espumante) de harina de semillas de ciruela de pan de jengibre y de cacahuete fueron estudiadas. Entre los parámetros nutricionales, la relación aminoácidos esenciales/aminoácidos totales $(E / T)$, el perfil de aminoácidos (AAS) y el coeficiente de eficacia proteica (PER) fueron estudiadas. Harina de semillas de ciruela de pan de jengibre (DGPSM) mostraron una alta calidad nutricional con unos valores de PER y de AAS de 2.35 y 65.53 respectivamente. El perfil de solubilidad de DGPSM fue similar al de la harina desengrasada de cacahuete (DPM), con una mínima solubilidad observada a $\mathrm{pH} 4$ y un máximo de solubilidad a $\mathrm{pH} 10$ y superior. Las capacidad de retención de agua y de aceite fueron 3.01 y $3.12 ; 2.96$ y $3.11 \mathrm{~g} / \mathrm{g}$ para DGPSM y DPM respectivamente. DGPSM mostró una buena capacidad espumante $(145 \mathrm{~mL} / 100 \mathrm{~mL})$ and estabilidad $(110 \mathrm{~mL}$ $/ 100 \mathrm{~mL}$ ) incluso después de 60 min a temperatura ambiente. La capacidad emulsionante de DGPSM fue del $29 \%$. Las densidades fueron 0.30 y $0.28 \mathrm{~g} / \mathrm{ml}$ para DGPSM y DPM respectivamente. Por último, DGPSM fue fácilmente hidrolizado por tripsina in vitro. Estos resultados mostraron que DGPSM tienen propiedades funcionales que pueden encontrar aplicación en la industria alimentaria.
\end{abstract}

PALABRAS CLAVE: Aminoácido - Calidad nutricional Ciruela de pan de jengibre - Digestibilidad in vitro de proteínas - Propiedades funcionales - Semilla oleaginosa .

\section{SUMMARY}

Nutritional and functional characteristics of gingerbread plum (Neocarya macrophylla): an underutilized oilseed.

The In-vitro protein digestibility, protein nutritional quality and functional characteristics (protein solubility, water/oil binding capacity, emulsifying capacity and foaming capacity) of gingerbread plum and peanut seed flour were studied. Among the nutritional parameters, the proportion of essential amino acids to total amino acids $(E / T)$, amino acid scores (AAS) and protein efficiency ratio (PER) were studied. Defatted gingerbread plum seed meal (DGPSM) showed a high nutritional quality with PER and AAS values of 2.35 and 65.53 respectively. The solubility profile of DGPSM was similar to that of defatted peanut meal (DPM), with minimum solubility observed at $\mathrm{pH} 4$ and maximum solubility at $\mathrm{pH} 10$ and higher. Water and oil holding capacities were 3.01 and $3.12 ; 2.96$ and $3.11 \mathrm{~g} / \mathrm{g}$ for DGPSM and DPM respectively. DGPSM showed good foaming capacity ( $145 \mathrm{~mL} / 100 \mathrm{~mL}$ ) and stability $(110 \mathrm{~mL} / 100 \mathrm{~mL})$ even after $60 \mathrm{~min}$ at room temperature. The emulsifying capacity of DGPSM was $29 \%$. Bulk densities were 0.30 and $0.28 \mathrm{~g} / \mathrm{mL}$ for DGPSM and DPM respectively. Finally, DGPSM was easily hydrolyzed by trypsin in vitro. These results show that DGPSM has functional properties that may find applications in the food industry.

KEY-WORDS: Amino acids - Functional properties Gingerbread plum - In vitro protein digestibility - Nutritional quality - Oilseed.

\section{INTRODUCTION}

Oilseeds comprise those seeds that contain reasonably high percentages of oil and about 20$25 \%$ protein. After removal of the oil they contain $50-60 \%$ protein (Altschul, 1958). Seeds included in this category are groundnut, soya bean, palm kernel, cotton seed, locust bean, melon seeds, conophor nut, castor bean, African oil bean, sunflower seed, rapeseed, sesame seed, linseed, safflower and other such seeds (Robellen et al., 1989). Some of these seeds are at present not well known and thus may be grossly underutilized in relation to their potential. One of these lesserknown oilseeds is gingerbread plum (Neocarya macrophylla) seed. Gingerbread plum belongs to chrysobalanaceae family. Gingerbread plum trees grow in arid and semiarid regions mainly in the Western part of Africa and Central America particularly Panama. The plant is semi-cultivated and its fruits are harvested from the ground.

The fruits are used in a variety of ways. Many are eaten fresh or are boiled with cereal. Fragrant syrups are often prepared as well; and gingerbread plum is also the basis for some drinks that prove much stronger than any fruit juice.

The kernels inside the seeds are eaten too. The gingerbread nuts are usually roasted and enjoyed like cashews or almonds. Some are consumed as snacks, others mixed into cooked dishes and a few are pressed to yield cooking oil (National Research Council, 2008). Like most oilseeds, gingerbread 
plum seeds are of high food value with about 40$60 \%$ oil and $21-25 \%$ protein contents (Burkill, 1985; Amza et al., 2010). The defatted gingerbread plum seed meal contains $61 \%$ protein. In addition, gingerbread plum seeds are a good source of certain amino acids, such as lysine, valine and phenylalanine (Amza et al., 2010), which is important for balancing the deficiency of these essential amino acids in cereal-based diets.

An appreciable amount of research was conducted on gingerbread plum fruit. These studies reported on the nutritional and functional characteristics of the flesh of gingerbread plum fruit (Frederick, 1961; Cook et al., 1998 and Audu et al., 2005). Interestingly, even though the seed is rich in protein and oil, very little information has been reported. Hence, the present study was undertaken on the utilization of gingerbread plum seed flour as a protein rich meal, by describing its nutritional quality and functional properties such as water holding, oil binding, foam and emulsification capacities, nitrogen solubility, and bulk density and also to evaluate the in-vitro digestibility behavior of the meal.

\section{MATERIALS AND METHODS}

\subsection{Starting materials}

Gingerbread plum seeds were collected in Birni N'Gaouré, the southern region of the Republic of Niger and provided by Alimentation Générale SARA. The seeds were milled using a laboratory scale hammer miller and the resulting paste was dispersed in $n$-hexane at a paste to $n$-hexane ratio of $1: 5(\mathrm{w} / \mathrm{v})$ and stirred for $4 \mathrm{~h}$ at room temperature. The experiment was repeated twice as described above. The n-hexane was decanted and the defatted gingerbread plum seed meal (DGPSM) was air dried for $24 \mathrm{~h}$ under a vacuum drier then sieved through a 60 mesh screen and stored at $5 \pm 1^{\circ} \mathrm{C}$ in sealed glass jars until use. Commercial peanuts were purchased from a local market (Wuxi, China). A molecular weight (14100-97400 Da) marker was purchased from Sigma-Aldrich, China Inc. (Shanghai, China). All chemicals used in the experiments were of analytical grade.

\subsection{Amino acid analysis}

Dried samples were digested with $\mathrm{HCl}(6 \mathrm{M})$ at $110^{\circ} \mathrm{C}$ for $24 \mathrm{~h}$ under nitrogen atmosphere. Reversed phase high performance liquid chromatography (RP-HPLC) analysis was carried out in an Agilent 1100 (Agilent Technologies, Palo Alto, CA, USA) assembly system after precolumn derivatization with o-phthaldialdehyde (OPA) (Jarret et al., 1986).

Each sample $(1 \mu \mathrm{L})$ was injected onto a Zorbax 80 A C18 column (i.d., $4.6 \times 180$ mm, Agilent Technologies) at $40^{\circ} \mathrm{C}$ with detection at $338 \mathrm{~nm}$. The mobile phase A was $7.35 \mathrm{mM} / \mathrm{L}$ sodium acetate/ triethylamine/ tetrahydrofuran (500:0.12: 2.5, v/v/v), adjusted to $\mathrm{pH} 7.2$ with acetic acid, while mobile phase $B(\mathrm{pH} 7.2)$ was $7.35 \mathrm{mM} / \mathrm{L}$ sodium acetate/m ethanol/acetonitrile $(1: 2: 2, \mathrm{v} / \mathrm{v} / \mathrm{v})$. The amino acid composition was expressed as $\mathrm{g}$ of amino acid per $100 \mathrm{~g}$ of protein.

\subsection{Protein nutritional parameters}

The nutritional parameters of whole gingerbread plum seed meal (WGPSM), defatted gingerbread plum seed meal (DGPSM), whole peanut meal (WPM) and defatted peanut meal (DPM) were calculated using their amino acid compositions including: 1) proportion of essential amino acids (E) to total amino acids ( $\mathrm{T}$ ) of proteins; 2) amino acid score $(A A S)=(\mathrm{mg}$ of amino acid/g of test protein/ $\mathrm{mg}$ of amino acid/g of FAO/WHO/UNU standard pattern) $\times 100$; 3) Predicted protein efficiency ratio (PER) values. The FAO/WHO reference pattern of essential amino acid requirements $(\mathrm{g} / 100 \mathrm{~g}$ of protein) (FAO/WHO 2007) was used as the standard. The predicted PER values of DGPSM and DPM were estimated by three regression equations developed by Alsmeyer et al. (1974).

$$
\begin{aligned}
& \text { I. PER }=-0.684+0.456 \text { (Leu) }-0.047 \text { (Pro) } \\
& \text { II. PER }=-0.468+0.454 \text { (Leu) }-0.105 \text { (Tyr) } \\
& \text { III. PER }=-1.816+0.435 \text { (Met) }+0.780 \text { (Leu) } \\
& +0.211 \text { (His) }-0.944 \text { (Tyr) }
\end{aligned}
$$

\subsection{SDS-PAGE}

SDS-PAGE was conducted on $12 \%$ separating and $4 \%$ stacking gels according to Laemmli (1970). An aliquot of $5 \mathrm{mg}$ was dissolved in $1 \mathrm{~mL}$ of $20 \mathrm{mM}$ Tris- $\mathrm{HCl}$ buffer at $\mathrm{pH}$ 7.1. The solution was then centrifuged at $12000 \times \mathrm{g}$ for two minutes to obtain the analytical sample. Coomassie brilliant blue $\mathrm{R}-250$ was used for staining.

\subsection{Protein solubility}

Protein solubility was determined according to the procedure of Bera and Mukherjee (1989). Protein dispersions $(0.1 \%, w / v)$ were prepared in $0.01 \mathrm{M}$ $\mathrm{Na} 2 \mathrm{HPO}$, adjusted to a specific value within the range of $\mathrm{pH} 2-10$ with $0.1 \mathrm{~N} \mathrm{HCl}$ or $0.1 \mathrm{NaOH}$. These suspensions were shaken (Lab Line Environ Shaker; Lab Line Instrument, Inc., Melrose Park, III., USA) for $30 \mathrm{~min}$ at room temperature (approximately $25 \pm 1^{\circ} \mathrm{C}$ ) and centrifuged at $4000 \times \mathrm{g}$ for $30 \mathrm{~min}$. Percent protein solubility was calculated as PS (\%) $=$ (protein content of sample/protein content of control) $\times 100$. The protein content of the dispersion $(0.1 \%, w / v)$ in $0.1 \mathrm{~N} \mathrm{NaOH}$ was used as the total protein content (or $100 \%$ protein solubility).

\subsection{In vitro protein digestibility}

In vitro protein digestibility was determined according to Elkhalil et al., (2001), with slight modifications. About $20 \mathrm{mg}$ of DGPSM and DPM in triplicate were dissolved in $10 \mathrm{~mL}$ of trypsin $(0.2$ $\mathrm{mg} / \mathrm{mL}$ in $100 \mathrm{mM}$ Tris- $\mathrm{HCl}$ buffer, $\mathrm{pH}$ 7.6). The 
suspension was incubated at $37^{\circ} \mathrm{C}$ for $2 \mathrm{~h}$. Hydrolysis was stopped by adding $5 \mathrm{~mL}$ of $50 \%$ trichloroacetic acid (TCA). The mixture was allowed to stand for $30 \mathrm{~min}$ at $4^{\circ} \mathrm{C}$ and was then centrifuged at $9500 \times \mathrm{g}$ for $30 \mathrm{~min}$ using a D-3756 Osterode am Harz model 4515 Centrifuge (Sigma, Germany). The resulting precipitate was dissolved in $5 \mathrm{~mL}$ of $\mathrm{NaOH}$ and protein concentration was measured using the micro-Kjeldahl method. Digestibility was calculated as follows.

$$
\text { Protein digestibility }(\%)=\frac{(A-B)}{A} \times 100
$$

Where: A - Total protein content $(\mathrm{mg})$ in the sample. B - Total protein content $(\mathrm{mg})$ in TCA precipítate.

\subsection{Foaming capacity and foam stability}

Foaming capacity was determined in triplicate using the method described by Makri et al. (2005). Dispersions of $1 \%$ sample $(\mathrm{w} / \mathrm{v})$ were prepared in de-ionized water and adjusted to $\mathrm{pH}$ 7.4. A volume of $100 \mathrm{ml}(\mathrm{VI})$ of meal suspension was blended for 3 min using a high-speed blender, poured into a $250 \mathrm{ml}$ graduated cylinder, and the volume of foam (VF) was immediately recorded. Foaming capacity (FC) was calculated using the following equation: $\mathrm{FC}=\mathrm{VF} / \mathrm{VI}$. Foaming stability was estimated as the percent of foam remaining after $60 \mathrm{~min}$.

\subsection{Emulsifying capacity}

Emulsifying capacity (EC) was measured using the procedure described by Rakesh and Metz (1973), with modifications. $0.5 \mathrm{~g}$ of each sample were transferred to a $250 \mathrm{~mL}$ beaker and dissolved in $50 \mathrm{~mL}$ of $0.5 \mathrm{~N} \mathrm{NaCl}$, and then $50 \mathrm{~mL}$ of soybean oil was added. The homogenizer equipped with a motorized stirrer driven by a rheostat Ultra-T18 homogenizer (Shanghai, China) was immersed in the mixture, and operated for $120 \mathrm{~s}$ at $10,000 \mathrm{rpm}$ to make an emulsion. The mixture was transferred to centrifuge tubes, kept in a water-bath at $90^{\circ} \mathrm{C}$ for $10 \mathrm{~min}$ and then centrifuged at $2800 \mathrm{~g}$ for $20 \mathrm{~min}$.

$$
\begin{aligned}
& E C=V_{A}-V_{R} / W_{S} \\
& V_{A}: \text { Volume of added oil } \\
& V_{R}: \text { Volume of released oil } \\
& W_{S} \text { : Weight of the sample }
\end{aligned}
$$

\subsection{Oil binding capacity}

Oil binding capacity was determined according to Chakraborty (1986). One gram $\left(W_{0}\right)$ of sample was added to pre-weighed $15-\mathrm{mL}$ centrifuge tubes and thoroughly mixed with $10 \mathrm{~mL}\left(\mathrm{~V}_{1}\right)$ of vegetable oil using a Vortex mixer. Samples were allowed to stand for $30 \mathrm{~min}$. The protein-oil mixture was centrifuged at $3000 \mathrm{~g}$ for $20 \mathrm{~min}$. Immediately after centrifugation, the supernatant was carefully poured into a $10 \mathrm{~mL}$ graduated cylinder, and the volume was recorded $\left(\mathrm{V}_{2}\right)$. Oil binding capacity (milliliter of oil per gram of sample) was calculated as $\mathrm{OBC}=\left(\mathrm{V}_{1}-\mathrm{V}_{2}\right) / \mathrm{W}_{0}$. Samples were analyzed in triplicate.

\subsection{Water holding capacity}

Water holding capacity was determined using the method outlined by Beuchat (1977). One gram of sample was added to pre-weighed 15-mL centrifuge tubes. For each sample, $10 \mathrm{ml}$ of distilled water were added and mixed using a Fisher Gene II vortex at the highest speed for $2 \mathrm{~min}$. After the mixture was thoroughly wetted, samples were allowed to stand at room temperature for $30 \mathrm{~min}$, and then centrifuged at $3000 \mathrm{~g}$ for $20 \mathrm{~min}$. The supernatant was decanted and the centrifuge tube containing sediment was weighed. Water holding capacity (grams of water per gram of protein) was calculated as $\mathrm{WHC}=\left(\mathrm{W}_{2}-\mathrm{W}_{1}\right) / \mathrm{W}_{0}$, where $\mathrm{W}_{0}$ is the weight of the dry sample $(\mathrm{g}), \mathrm{W}_{1}$ is the weight of the tube plus the dry sample $(g)$, and $W_{2}$ is the weight of the tube plus the sediment $(\mathrm{g})$. Samples were analyzed in triplicate.

\subsection{Bulk density}

Bulk density was determined using the method described by Monteiro and Prakash (1994). A calibrated plastic centrifuge tube was weighed $\left(\mathrm{W}_{1}\right)$, protein samples were filled to $25 \mathrm{~mL}$ and the tubes were tapped to eliminate the spaces between the particles, the volume was taken as the volume of the sample. The tube was weighed again $\left(W_{2}\right)$. From the difference in weight, the bulk density of the protein samples was calculated and expressed as grams per milliliter $(\mathrm{g} / \mathrm{mL})$.

\subsection{Differential scanning calorimetry (DSC)}

The thermal properties of defatted gingerbread seed meal and defatted peanut meal were evaluated using differential scanning calorimetry (Pyris-I-DSC, Perkin-Elmer Corp., Norwalk, Conn., USA). $70 \mathrm{mg}$ of various samples were dissolved in $1 \mathrm{~mL}$ of $0.05 \mathrm{M}$ phosphate buffer $(\mathrm{pH} 7.0)$ containing $0.1 \mathrm{M} \mathrm{NaCl}$. The solutions (45 $\mu \mathrm{L})$ were transferred and hermetically sealed in a stainless steel pan. The samples were heated by scanning from 25 to $135^{\circ} \mathrm{C}$ at a rate of $10^{\circ} \mathrm{C}$ per min against a reference containing $45 \mu \mathrm{L}$ buffer without protein in a differential scanning calorimeter (Perkin-Elmer Corp., Norwalk, Conn., USA.). The denaturation peak temperature and enthalpy were calculated using a thermal analysis data software program.

\subsection{Scanning electron microscopy (SEM)}

Scanning electron microscopic (SEM) studies were carried out using a scanning electron microscope (Quanta-200 FEI, Netherland). The samples were coated before loading to the scanning electron 
microscopy. The coated samples were loaded into the system and the image was viewed under $5.0 \mathrm{KV}$ potential using secondary electron image. The image was captured using $12 \mathrm{~mm}$ Ricoh Camera of 600x Mag.

\subsection{Statistical analysis}

All experiments were conducted at least in triplicate with SPSS Inc. software (version 13.0). One-way analysis of variance (ANOVA) was used to determine significant differences between means, with the significance level taken at $a=0.05$. Tukey's HSD test was used to perform multiple comparisons between means.

\section{RESULTS AND DISCUSSIONS}

\subsection{Amino acid composition}

The protein contents of defatted gingerbread plum seed meal (DGPSM) and defatted peanut meal (DPM) increased after defatting the raw materials; gingerbread plum and peanut paste (Table 1). Indeed, it is well established that after the removal of oil, the protein content of oilseeds increased to about 50-60\% (Altschul, 1958). Defatted gingerbread plum seed meal (DGPSM) and whole gingerbread plum seed meal (WGPSM) contained the highest amounts of sulfurcontaining amino acids whereas, basic amino acids were lower in both samples as compared with defatted peanut meal (DPM) and whole peanut meal (WPM). Regarding hydrophobic, uncharged polar, acidic and aromatic amino acids, DGPSM showed slightly higher contents as compared with DPM.

\subsection{Nutritional protein quality}

The protein quality, also known as the nutritional or nutritive value, depends on the level at which it provides essential amino acids needed for overall body health, maintenance, and growth (Ke-Xue et al., 2006). Since a direct assessment of protein nutritional value in human subjects is impractical for regulatory purposes, methods based on in vitro and animal bioassays for assessment of protein quality have been developed.

In this work, amino acid composition has been used as a basis for estimating the nutritional quality of gingerbread plum seed and peanut meal proteins. Results of the ratio of essential to total amino acids (E/T), amino acid score (AAS) and protein efficiency ratio (PER) of whole gingerbread plum seed meal (WGPSM), defatted gingerbread plum seed meal (DGPSM), whole peanut meal (WPM) and defatted peanut meal(DPM) are shown in Table 2.

The ratio of essential to total amino acids $(E / T)$ in all samples was higher than recommended by WHO (at least 36\%), and DGPSM with $41.93 \%$ ratio, ranked the highest (Table 2 ).

In all samples, lysine was the most limiting amino acid, followed by threonine and tryptophan. Baldwin (1986) reported that lysine, leucine, isoleucine and valine were the limiting amino acids in many oilseed proteins. However, amino acid scores (AAS) based on limiting amino acids were proportional to lysine content in this study. WGPSM was found to have the highest AAS value (68.63) followed by DGPSM (65.53) and DPM (60.07) with a significant difference $(P<$ 0.05) (Table 2).

In general, PER (Protein Efficiency Ratio) below 1.5 implies a protein of low or poor quality; whereas PER between 1.5 and 2.0 indicates an intermediate protein quality; and then PER above 2.0 means protein of good to high quality (Friedman, 1996). The predicted PER values of all the samples are in the range of protein of an intermediate to good quality (Table 2). The PER values of WGPSM and WPM were quite satisfactory compared with a standard casein PER of 2.5 (Friedman, 1996).

Table 1

Distribution of gingerbread plum seed and peanut meal amino acids classified according to similar chemical properties $(\mathrm{g} / 100 \mathrm{~g}$ of protein)

\begin{tabular}{lcccc}
\hline \multicolumn{1}{c}{ Group } & WGPSM $^{1}$ & DGPSM $^{2}$ & WPM $^{3}$ & DPM $^{4}$ \\
\hline Hydrophobic (nonpolar) $^{\mathrm{a}}$ & $36.99 \pm 0.02$ & $38.68 \pm 0.01$ & $36.73 \pm 0.01$ & $37.28 \pm 0.03$ \\
Unchraged polar $^{\mathrm{b}}$ & $11.73 \pm 0.03$ & $12.80 \pm 0.05$ & $12.57 \pm 0.03$ & $12.29 \pm 0.01$ \\
Basic $^{c}$ & $14.73 \pm 0.02$ & $16.34 \pm 0.04$ & $16.97 \pm 0.06$ & $16.80 \pm 0.03$ \\
Acidic $^{\mathrm{d}}$ & $29.14 \pm 0.02$ & $29.86 \pm 0.02$ & $28.29 \pm 0.01$ & $29.39 \pm 0.02$ \\
Sulfur containing $^{\mathrm{e}}$ & $2.83 \pm 0.03$ & $3.24 \pm 0.01$ & $2.36 \pm 0.01$ & $2.44 \pm 0.04$ \\
Aromatic $^{\dagger}$ & $9.54 \pm 0.02$ & $10.41 \pm 0.02$ & $9.69 \pm 0.06$ & $9.77 \pm 0.01$ \\
Total protein & 104.96 & 111.33 & 106.61 & 107.97 \\
\hline
\end{tabular}

Values are means \pm standard deviation of three determinations. ${ }^{1}$ WGPSM: whole gingerbread plum seed meal, ${ }^{2}$ DGPSM: defatted gingerbread plum seed meal, ${ }^{3}$ WPM: whole peanut meal, ${ }^{4}$ DPM: defatted peanut meal. ${ }^{a} G l y$, Ala, Val, Leu, Pro, Met, Phe, Trp, and lle. ${ }^{6}$ Ser, Thr, Cys, and Tyr. ${ }^{\circ}$ Lys, Arg, and His. ${ }^{d}$ Asp and Glu. ${ }^{e}$ Cys and Met. ${ }^{~}$ Phe, Tyr, and Trp. 
Table 2

Nutritional evaluation of gingerbread plum seed and peanut meal proteins

\begin{tabular}{ccccc}
\hline Parameters & WGPSM $^{1}$ & DGPSM $^{2}$ & WPM $^{3}$ & DPM $^{4}$ \\
\hline LAA & & & & \\
Threonine & $84.43 \pm 0.95 \mathrm{c}$ & $80.86 \pm 1.04 \mathrm{a}$ & $86.65 \pm 1.43 \mathrm{c}$ & $60.07 \pm 0.95 \mathrm{~b}$ \\
Met+Cys & $*$ & $*$ & $113.27 \pm 1.27 \mathrm{~b}$ & $128.33 \pm 0.70 \mathrm{a}$ \\
Leucine & $96.98 \pm 0.67 \mathrm{a}$ & $*$ & $91.51 \pm 0.70 \mathrm{~b}$ & $100.39 \pm 0.75 \mathrm{~b}$ \\
Lysine & $68.63 \pm 0.90 \mathrm{a}$ & $65.53 \pm 1.51 \mathrm{~d}$ & $47.22 \pm 1.15 \mathrm{c}$ & $76.5 \pm 0.60 \mathrm{~b}$ \\
Tryptophan & $69.77 \pm 0.89 \mathrm{c}$ & $82.24 \pm 1.29 \mathrm{~d}$ & $91.55 \pm 0.67 \mathrm{a}$ & $95.90 \pm 0.70 \mathrm{~b}$ \\
AAS & 68.63 & 65.53 & 47.22 & 60.07 \\
E/T (\%) & $39.58 \pm 0.71 \mathrm{a}$ & $41.93 \pm 0.70 \mathrm{a}$ & $39.79 \pm 0.61 \mathrm{a}$ & $38.95 \pm 0.94 \mathrm{~b}$ \\
\hline Estimated PER & & & & $2.34 \pm 0.39$ \\
I & $2.26 \pm 0.49$ & $2.35 \pm 0.38$ & $2.25 \pm 0.56$ & $2.37 \pm 0.28$ \\
III & $2.32 \pm 0.41$ & $2.33 \pm 0.56$ & $2.19 \pm 0.31$ & $2.31 \pm 0.34$ \\
\hline
\end{tabular}

${ }^{1}$ WGPSM: whole gingerbread plum seed meal, ${ }^{2}$ DGPSM: defatted gingerbread plum seed meal, ${ }^{3}$ WPM: whole peanut meal and ${ }^{4}$ DPM: defatted peanut meal. Values are means \pm standard deviations of triplicates. Column with different letters indicate statistical differences $(P<0.05)$. LAA: limiting amino acids with their respective amino acid score; *: Not limiting for the indicated sample; AAS: amino acid score; E/T: proportion of essential amino acids $(E)$ to total amino acids (T); PER: protein efficiency ratio.

\subsection{Sodium dodecyl sulfate polyacrylamide gel electrophoresis}

The SDS-PAGE profiles of defatted gingerbread plum seed meal (DGPSM) and defatted peanut meal (DPM) are shown in Figure 1. DGPSM and DPM revealed polypeptides of a wide range of molecular weights. Both samples indicated polypeptides above $45 \mathrm{kDa}$ (Figure 1). Compared with DPM, DGPSM possessed fewer polypeptide bands. The SDS-PAGE pattern indicated nine major bands in DPM with estimated molecular weight ranging from 14.4 to above $66.2 \mathrm{kDa}$ and six bands in DGPSM along with some minor bands in the two samples. Clearly, based on band width and intensity, five major polypeptides with molecular weight of 14.4, 20.1, 31.0, 43.0 and $66.2 \mathrm{kDa}$ were identified in the DPM sample while DGPSM showed four intense polypeptides with molecular weight of $14.4,31.0,31.0-43.0$ and $43.0-66.2 \mathrm{kDa}$. The present data are similar to those reported by Prasad (1988) for sunflower albumins.

\subsection{Nitrogen solubility}

Protein solubility at various $\mathrm{pH}$ values may serve as a useful indicator of how well proteins will perform when incorporated into food systems and also the extent of protein denaturation because of heat or chemical treatment (Horax, 2004). The nitrogen solubility profile at varying $\mathrm{pH}$ (from 2.0 to 12.0) of defatted gingerbread plum seed meal (DGPSM) and defatted peanut meal (DPM) is minimum at $\mathrm{pH} 4.0$ and increased gradually below $\mathrm{pH} 4.0$ and above $\mathrm{pH}$ 6.0 (Figure 2). Above pH 8.0, the solubility continued to increase but at a slower rate and the maximum nitrogen solubility of DGPSM and DPM was observed at $\mathrm{pH} 10.0$. Beyond $\mathrm{pH} 10.0$, the solubility did not show a significant increase. The underlying mechanism of solubilization at alkaline $\mathrm{pH}$ (especially at $\mathrm{pH}>10.0$ ) may be related to the dissociation of protein molecules (Goring, 1955).

The solubility pattern of DGPSM was found similar to that of DPM. Shen (1981), found the

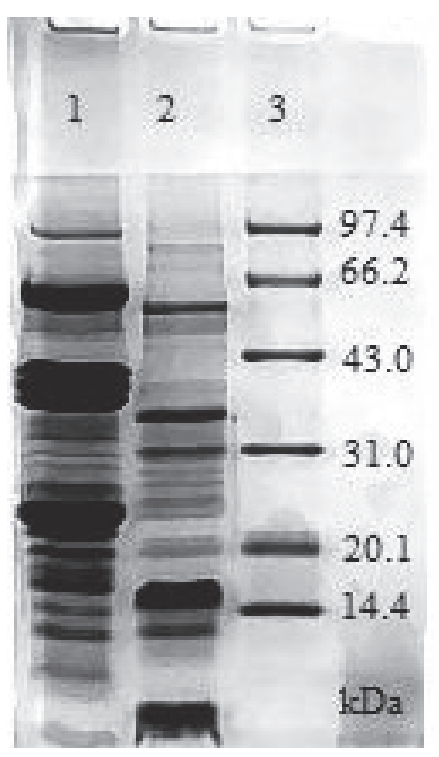

Figure 1

SDS-PAGE profiles of defatted gingerbread plum seed meal (DGPSM) and defatted peanut meal (DPM). Lane 1: DPM; lane 2: DGPSM; lane 3: Low molecular weight standards: rabit phosphorylase $\mathrm{B}(97.4 \mathrm{kDa})$, bovine serum albumin $(66.2 \mathrm{kDa})$, rabit actin $(43.0 \mathrm{kDa})$, bovine carbonic anhydrase $(31.0 \mathrm{kDa})$, trypsin inhibitor (20.1 kDa) and hen egg white lysozyme (14.4 kDa). 


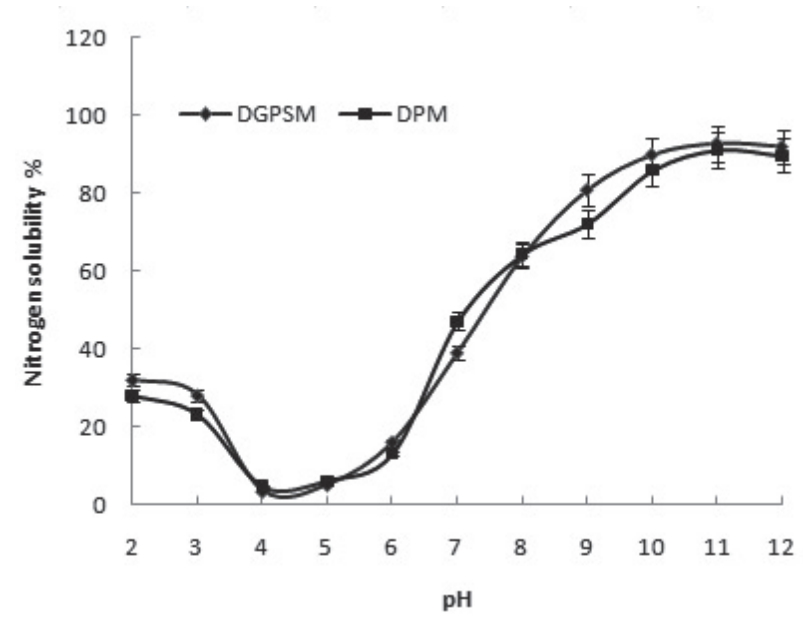

Figure 2

Effects of $\mathrm{pH}$ on the solubility of defatted gingerbread plum seed meal (DGPSM) and defatted peanut meal (DPM). Values represent the means \pm standard deviation of triplicates.

same similarity of nitrogen solubility between peanut and soy proteins suggesting a possible similarity in functional properties and protein compositions of the two plant proteins. In fact, the amino acid profiles of peanut protein and soy protein are comparable with the exception of a lower lysine level in peanut (USDA-NAL, 2005). These previous findings implied how similar gingerbread plum seeds are to peanut and soybean in terms of their functional properties and protein composition.

\subsection{In vitro protein digestibility (IVPD)}

The in-vitro digestibility of defatted gingerbread plum seed meal (DGPSM) and defatted peanut meal (DPM) were evaluated by TCA-soluble nitrogen release during the digestion of trypsin. The IVPD of DGPSM and DPM were $57.43 \%$ and $50.18 \%$ respectively and were significantly different $(P<0.05)$ (Table 3).

The results of this study are higher when compared with the values reported by Maha et al. (2009) for uncooked soybean flour (30.5\%) and lower than the results reported by Ali et al. (2009) for soybean meal (76.08\%).

\subsection{Foaming capacity (FC) and foaming stability (FS)}

The formation of protein based foams involves the diffusion of soluble proteins toward the airwater interface, rapid conformational change and rearrangement at the interface. The foam stability requires formation of a thick, cohesive, and viscoelastic film around each gas bubble (Damodaran, 1994).

Defatted gingerbread plum seed meal (DGPSM) had higher foaming capacity than defatted peanut meal (DPM) (Table 3). Radha et al. (2007) also observed that peanut flour shows less foaming capacity and foaming stability $(40 \pm 2 \%$ and $10 \pm 1 \mathrm{~mL})$ compared to foaming capacities and foaming stabilities of soy flour and sesame flour. As the standing time increases, foam stability decreases (Figure 3). Our results agreed with those reported by Abdeen (1987), who found that the foaming stability of lupin protein isolates decreased with increasing time. Also after $1.5 \mathrm{~h}$ standing, the foams were less stable. This decrease may be explained by the collapsing and bursting of the formed air bubbles.

\subsection{Emulsifying capacity (EC)}

Food emulsions are thermodynamically unstable mixtures of immiscible liquids (water and oil). The formation and stability of emulsion is very important in food systems such as salad dressings. Proteins are composed of charged amino acids, noncharged polar amino acids and nonpolar amino acids, which makes protein a possible emulsifier, the surfactant possessing both hydrophilic and hydrophobic properties which are able to interact with both water and oil in food systems (Jianmei et al., 2007). The emulsifying capacities of defatted gingerbread plum seed meal (DGPSM) and defatted peanut meal (DPM) are shown in Table 3. DPM (34.67\%) had higher emulsifying capacity compared with DGPSM (29\%). Our results agreed

Table 3

Functional properties of gingerbread plum seed and peanut meal proteins

\begin{tabular}{lrr}
\hline \multicolumn{1}{c}{ Functional property } & \multicolumn{1}{c}{ DGPSM $^{1}$} & \multicolumn{1}{c}{ DPM $^{2}$} \\
\hline In vitro protein digestibility $(\%)$ & $57.43 \pm 1.37$ & $50.18 \pm 0.78$ \\
Foaming capacity $(\mathrm{ml} / 100 \mathrm{~mL})$ & $145 \pm 2.31$ & $133 \pm 1.53$ \\
Emulsifying capacity $(\%)$ & $29.0 \pm 2.65$ & $34.67 \pm 4.04$ \\
Water hoding capacity $(\mathrm{g} / \mathrm{g})$ & $3.01 \pm 0.12$ & $2.96 \pm 0.05$ \\
Oil binding capacity $(\mathrm{g} / \mathrm{g})$ & $3.12 \pm 0.19$ & $3.11 \pm 0.14$ \\
Bulk density $(\mathrm{g} / \mathrm{mL})$ & $0.30 \pm 0.02$ & $0.28 \pm 0.012$ \\
\hline
\end{tabular}

Values are means \pm standard deviation of three determinations.

${ }^{1}$ DGPSM: defatted gingerbread plum seed meal, ${ }^{2}$ DPM: defatted peanut meal. 


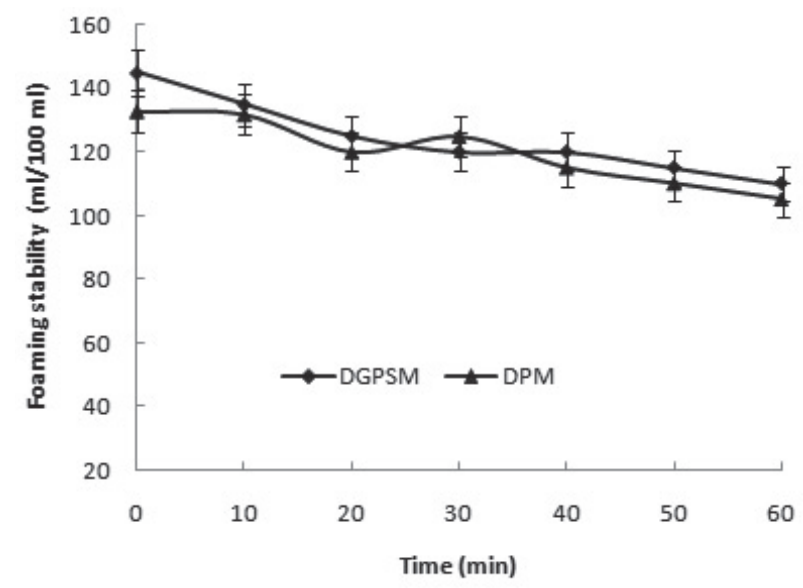

Figure 3

Foaming stability of defatted gingerbread plum seed meal (DGPSM) and defatted peanut meal (DPM). Values represent the means \pm standard deviation of triplicates.

with Aremu et al. (2006) and Oladele and Aina (2007) who reported that emulsifying capacity is closely associated with protein surface hydrophobicity.

Indeed, surface hydrophobicity is an important factor in determining emulsifying properties. It was previously reported that hydrophobicity exposed by a protein would allow a better molecular anchorage to be established in the oil-water interface, giving more stable emulsions (Nakai et al., 1986; Matsudomi et al., 1985). However, DGPSM contained more hydrophobic amino acid residues than DPM (Table 1). Therefore, the higher emulsifying capacity exhibited by DPM might be due to its lower hydrophobic amino acid content.

\subsection{Water holding and oil binding capacities}

The interactions of water and oil with proteins are very important in food systems because of their effects on the flavor and texture of foods. Intrinsic factors affecting the water binding of food protein include amino acid composition, protein conformation and surface hydrophobicity/polarity (Barbut, 1999). The results on the water and oil holding capacities of defatted gingerbread plum seed meal (DGPSM) and defatted peanut meal (DPM) are shown in Table 3. DGPSM showed better water absorption $(3.01 \mathrm{~g} / \mathrm{g})$ than DPM $(2.96 \mathrm{~g} / \mathrm{g})$. The oil binding capacity values were similar, $3.12 \mathrm{~g} / \mathrm{g}$ and $3.11 \mathrm{~g} / \mathrm{g}$ for DGPSM and DPM respectively. These binding capacities were higher than those reported by Neto et al. (2001) for the water and oil absorption capacities of cashew nut proteins.

\subsection{Bulk density}

Bulk density depends on the attractive interparticle forces, particle size and number of contact positions (Peleg and Bagley, 1983) and it is important for determining packaging requirements, material handling and application in wet processing in the food industry. Table 3 shows that the bulk density of defatted gingerbread plum seed meal (DGPSM) $(0.30 \mathrm{~g} / \mathrm{mL})$ was higher than that of the defatted peanut meal (DPM) $(0.28 \mathrm{~g} / \mathrm{mL})$.

These bulk density values are in the range of the values reported by Adeyeye and Adamu (2003) for various samples of extrusion texturized soya products with varied protein and soluble sugar contents $(0.2382-0.4460 \mathrm{~g} / \mathrm{mL})$ although are lower than the values reported by Njintang et al. (2001) on dry red bean flour, 0.61 to $0.63 \mathrm{~g} / \mathrm{mL}$.

\subsection{Differential Scanning Calorimetry (DSC)}

DSC is a valuable tool for assessing the potential of protein isolates or related high protein content products as functional ingredients in different food systems, where heat processing is required. Because the functional properties of protein rich products are greatly influenced by their conformation, DSC is applied to protein isolates and related products as a technique highly sensitive to conformational changes (Gorinstein et al., 1996). The DSC characteristics of defatted gingerbread plum seed meal (DGPSM) and defatted peanut meal (DPM) are summarized in Table 4.

DGPSM has a denaturation temperature or peak maximum temperature (Td) of approximately $78^{\circ} \mathrm{C}$ while DPM had two peaks with $\mathrm{Td}$ values of

Table 4

Differential scanning calorimetry characteristics of defatted gingerbread plum seed meal (DGPSM) and defatted peanut meal (DPM)

\begin{tabular}{crrr}
\hline \multirow{2}{*}{ Thermogram } & \multicolumn{1}{c}{ DGPSM } & \multicolumn{1}{c}{ DPM } \\
\cline { 3 - 4 } & & \multicolumn{1}{c}{ peak 1 } & \multicolumn{1}{c}{ peak 2 } \\
\hline $\mathrm{T}_{0}^{\mathrm{b}}\left({ }^{\circ} \mathrm{C}\right)$ & $77.64 \pm 0.66$ & $90.34 \pm 0.83$ & $97.19 \pm 0.65$ \\
$\mathrm{~T}_{\mathrm{d}}^{\mathrm{c}}\left({ }^{\circ} \mathrm{C}\right)$ & $78.12 \pm 1.20$ & $91.72 \pm 0.40$ & $98.94 \pm 0.73$ \\
$\Delta H^{\mathrm{d}}(\mathrm{J} / \mathrm{g})$ & $0.0054 \pm 0.96$ & $0.0080 \pm 0.37$ & $0.0152 \pm 0.54$ \\
$\Delta T_{1 / 2}{ }^{\mathrm{e}}\left({ }^{\circ} \mathrm{C}\right)$ & $5.79 \pm 0.30$ & $6.58 \pm 0.49$ & $7.81 \pm 0.42$ \\
\hline
\end{tabular}

${ }^{\mathrm{a}}$ Means \pm standard deviations of triplícate analyses. ${ }^{\mathrm{b}} \mathrm{On}-\mathrm{set}$ temperature of denaturation.

${ }^{c}$ Thermal denaturation temperature. ${ }^{d}$ Enthalpy changes of the endotherm. ${ }^{e}$ Width at half peak height of endothermic peak. 
90 and $97^{\circ} \mathrm{C}$ respectively. The reaction enthalpy $(\Delta \mathrm{H})$ value of DGPSM was $0.0054 \mathrm{~J} / \mathrm{g}$ and the values for DPM were 0.080 and $0.152 \mathrm{~J} / \mathrm{g}$ respectively. The $\mathrm{Td}$ and $\Delta H$ for DPM were similar to those reported by Kisung et al. (1996) for coconut proteins.

\subsection{Scanning electron microscopy (SEM)}

Micro structural changes produced in the flour after deffating were examined by scanning electron microscopy (Figure 4). The two meals were degraded into small fragments after defatting. Results showed that flour particles were clustered together and degradation of defatted flour particles takes place during the defatting process. These results were similar to those reported by Radha et al. (2007); Wu et al. (2009). Scanning electron micrographs of DGPSM and DPM obtained under the same parameters (HV- 50.0 KV; Mag -600x; Spot 4.0 and $100 \mu \mathrm{m})$ sh ow that DPM has sl ightly larger particles than DGPSM (Figure 4).

\section{CONCLUSIONS}

This investigation reveals that defatted gingerbread plum seed meal (DGPSM) and defatted peanut meal (DPM) were relatively comparable in term of their nutritional quality and functional properties. Both samples show similar SDS-PAGE patterns and results from DSC and SEM show the changes in the respective meal profiles after the removal of fat. Based on the foregoing, gingerbread plum seeds can be considered as part of all the oleaginous fruit and seeds related to peanuts and the other well known oilseeds that have been more thoroughly

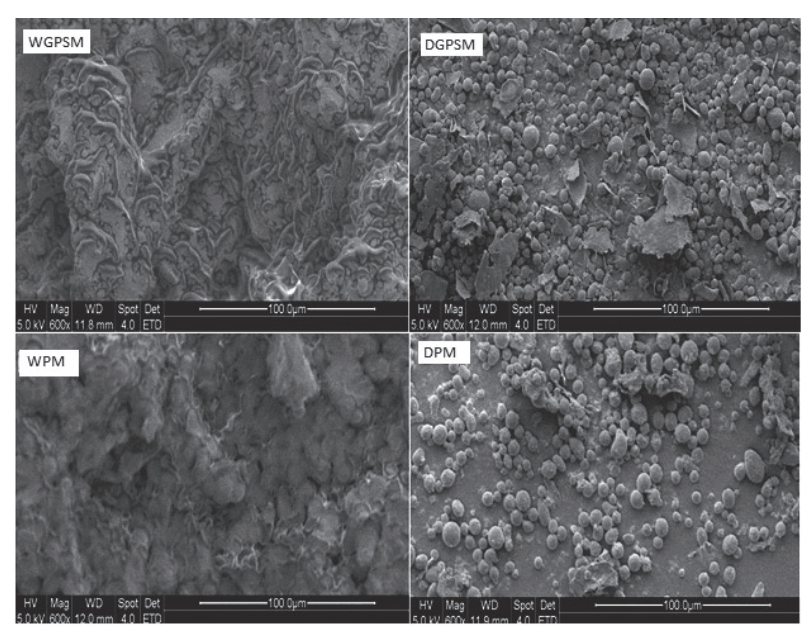

Figure 4

Scanning electron microscopic (SEM) pictures of whole gingerbread plum seed meal (WGPSM), defatted gingerbread plum seed meal (DGPSM), whole peanut meal (WPM) and defatted peanut meal (DPM). investigated and extensively used due to their potential. Therefore, gingerbread plum seeds could be of interest in areas where peanut and its related products and other oilseeds found useful applications.

\section{REFERENCES}

Abdeen EMI. 1987. Studies on chemistry and technology of some plant foods. MSc thesis, Faculty of Agriculture, Kafr El-Sheikh, Tanta University, Egypt.

Adeyeye El, Adamu AS. 2005. Chemical composition and food properties of Gymnarchus niloticus (Trunk fish). Biosci. Biotech. Res. Asia. 3, 265-272.

Ali H, Haque MM, Chowdhury MMR, Shariful MI. 2009. In vitro protein digestibility of different feed ingredients in Thai koi (Anabas testudineus). J. Bangladesh Agril. Univ. 7, 205-210.

Alsmeyer RH, Cunningham AE, Happich ML. 1974. Equations to predict PER from amino acid analysis. Food Technol. 28, 34-38.

Altschul AM. 1958. Processed plant protein foodstuffs. Academic Press, New York.

Amza T, Amadou I, Mohamed TK, Kexue Z, Huiming Z. 2010. Chemical and Nutrient Analysis of Gingerbread Plum (Neocarya macrophylla) Seeds. Adv. J. Food Sci. Technol. 2, 191-195.

Aremu MO, Olonisakin A, Atolaye BO, Ogbu CF. 2006. Some nutritional and functional studies of prosopis Africana. Electron J. Env. Agric. Food Chem. 5, 16401648.

Audu OT, Oyewale AO, Amupitan JO. 2005. The biological activities of secondary metabolites of Parinari macrophylla Sabine. Chem. Class J. 2, 19-21.

Baldwin AR. 1986. World Conference on Emerging Technologies in the Fats and Oils Industry. The American Oil Chemists Society.

Barbut S. 1999. Determining water and fat holding. In Hall GM (Ed.) Methods of testing protein functionality. Blackie Academic and profesional, New York, 186225.

Bera MB, Mukherjee RK. 1989. Solubility, emulsifying, and foaming properties of rice bran protein concentrates. J. Food Sci. 54, 142-145.

Beuchat LR. 1977. Functional and electrophoretic characteristics of succinylated peanut flour protein. J. Agric. Food Chem. 25, 258-261.

Burkill HM. 1985. The Useful Plants of West Tropical Africa. 2nd Edition, Royal Botanic Gardens Kew, England.

Chakraborty P. 1986. Coconut protein isolate by ultrafiltration. In LeMeguer M, Jelen P (Eds.) Food engineering and process applications. Elsevier Applied Science Publishers, New York, 308-315.

Cook JA, VanderJagt DJ, Dasgupta A, Mounkaila G, Glew RS, Blackwell W, Glew RH. 1998. Use of the trolox assay to estimate the antioxidant content of seventeen edible wild plants of Niger. Life Sci. 63, 105-110.

Damodaran S. 1994. Structure-function relationship of food proteins. In Hettiarachchy NS, Zieger GR (Eds.) Protein functionality in food systems. Marcel Dekker, New York, 190-225.

Elkhalil EAI, El-Tinay AH, Mohamed BE, Elshseikh EAE. 2001. Effect of malt pretreatment on phytic acid and in vitro protein digestibility of sorghum flour. Food Chem. 72, 29-32. 
FAO. 2007. Protein and amino acid requirements in human nutrition. Report of a joint WHO/FAO/UNU expert consultation. Geneva, Switzerland. (WHO technical report series, 935).

Frederick RI. 1961. Woody plants of Ghana. Oxford University Press, London.

Friedman M. 1996. Nutritional value of proteins from different food sources. A review. J. Agric. Food Chem. 44, 6-29.

Goring DAI, Johnson P. 1955. The preparation and stability of ultracentrifugally monodisperse edestin. Arch. Biochem. Biophys. 56, 448-458.

Gorinstein S, Zemser M, Paredes-Lopez O. 1996. Structural stability of globulins. J. Agric. Food Chem. 44, 100-105.

Horax R, Hettiarachy NS, Chen P, Jalaluddin M. 2004. Functional Properties of Protein Isolate from Cowpea (Vigna unguiculata L. Walp.). J Food Sci. 69, 119- 121.

Jarrett HW, Cooksy KD, Ellis B, Anderson JM. 1986. The separation of o-phthalaldehyde derivatives of amino acids by reversed phase chromatography on octylsilica columns. Anal. Biochem. 153, 189-198.

Jianmei Y, Mohamed A, Ipek G. 2007. Peanut protein concentrate: Production and functional properties as affected by processing. Food Chem. 103, 121-129.

Kisung K, Kwan HP, Khee CR. 1996. Fractionation and Characterization of Proteins from Coconut (Cocos nucifera L.). J. Agric. Food Chem. 44, 1741-1745.

Laemmli UK. 1970. Cleavage of structural proteins during the assembly of the head of bacteriophage T4. Nature. 227, 680-685.

Maha AM, Abdullahi HE, Isam AA, Elfadil EB. 2009 Supplementation of peral millet with soybean: Changes in protein digestibility, amino acid composition and sensory quality during processing. EJEAFChe. 8, 1068-1076.

Makri E, Papalamprou E, Doxastakis G. 2005. Study of functional properties of seed storage proteins from indigenous European legume crops (lupin, pea, broad bean) in admixture with polysaccharides. Food Hydrocolloids. 19, 583-594.

Matsudomi N, Sasaki T, Kayo A, Kobayashi K. 1985. Conformational changes and functional properties of acid-modified soy protein. J. Agric. Food Sci. 49, 1251-1256.

Monteiro PV, Prakash V. 1994. Functional properties of homogeneous protein fractions from peanut (Arachi hypogaea L.). J. Agric. Food Chem. 42, 274-278.
Nakai S, Li Can E, Hayakawa S. 1986. Contribution of protein hydrophobicity to its functionality. Narhung. 30, 327-336.

National Research Council. 2008. Lost Crops of Africa. National. Academies Press, Washington, D.C.

Neto VQ, Narain N, Silva JB, Bora PS. 2001. Functional properties of raw and heat processed cashew nut (Anacardium occidentale, L.) kernel protein isolates. Nahrung/Food. 45, 258-262.

Njintang NY, Mbofung C M, Waldron KW. 2001. In vitro protein digestibility and physicochemical properties of dry red bean (Phaseolus vulgaris) flour: Effect of processing and incorporation of soybean and cowpea Flour. J. Agric. Food Chem. 49, 2465-2471.

Oladele AK, Aina JO. 2007. Chemical composition and functional properties of flour produced from two varieties of tiger nut (Cyperus esculentus). Af. $J$. Biotechnol. 6, 2473-2476.

Peleg M. 1983. Physical characteristics of food powders. In Peleg M, Bagley EB (eds.) Physical properties of foods. AVI, Westport, 293-324.

Prasad DT. 1988. Studies on the sunflower albumins with chlorogenic acid. J. Agric. Food Chem. 36, 450-452.

Radha C, Kumar PR, Prakash V. 2007. Preparation and characterization of a protein hydrolysates from an oilseed flour mixture. Food Chem. 106, 1166-1174.

Rakesh J, Metz A. 1973. Acid precipitated fish protein isolate exhibits good functional properties. Food Product. Dev. 7, 18--24.

Robellen G, Downey RK, Ashri A. 1989. Oil Crops of the World. McGraw-Hill Publishing Co., UK.

Shen JL. 1981. Solubility and viscosity. In Cherry JP (Ed.) Protein functionality in Foods. Spring, Washington, DC.

USDA-NAL. 2005. United States Department of Agricultural-National Agricultural Library. USDA Nutrient Database for Standard Reference, Release 18. http://www.nal.usda.gov/fnic/foodcomp/cgi-bin/ list_nut_edit.pl.

Wu H, Wang Q, Ma T, Ren J. 2009. Comparative studies on the functional properties of various protein concentrate preparations of peanut protein. Food Res. Int. 42, 343-348.

Zhu KX, Zhou HM, Qian, HF. 2006. Proteins extracted from defatted wheat germ: nutritional and structural properties. Cereal Chem. 83, 69-75.

Recibido: 25/8/10 Aceptado: 10/12/10 